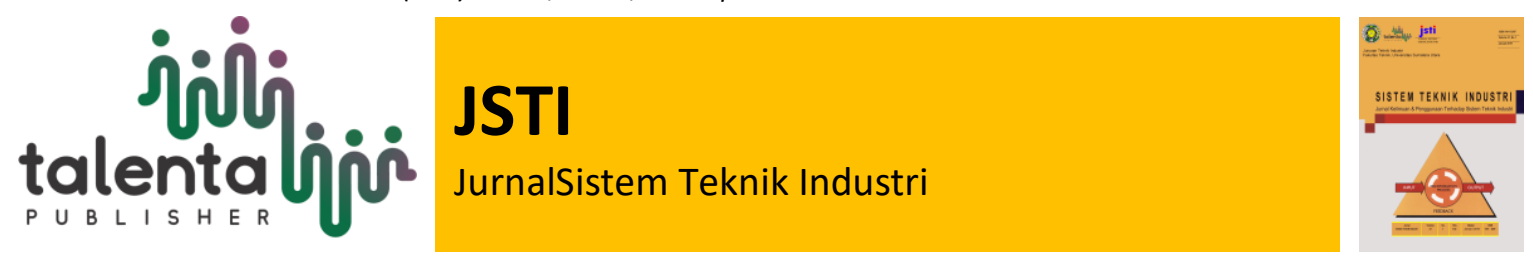

\title{
Penerapan Lean Kaizen untukMeningkatkan Produktivitas Line Painting pada Bagian Produksi Automotive dengan Metode PDCA
}

\section{Hayu Kartika}

Teknik Industri, Universitas Mercu Buana

\begin{abstract}
This paper was conducted in the automotive industry, the purpose of this study was to improve the productivity of workmanship in the Line Painting process in the production department. The focus of this research is: to see the waste that occurs in this part of the process this is because in the process productivity is still far below the target set by the company, so it needs to be improved in the process. Improvements were made using the Lean concept combined with the PDCA method. From the results of repairs carried out, it was found that during the Line Painting process there was a lot of waste loss time, then improvements were made with the application of Lean to get an increase or improvement in productivity by $80.6 \%$ which previously productivity only reached $71 \%$. From this research it is proven that by implementing Lean, this can significantly increase productivity
\end{abstract}

Keyword:Kaizen, Lean, Waste, PDCA, Productivity

\begin{abstract}
Abstrak.Penelitian ini dilakukan pada industri automotive, tujuan penelitian ini adalah untuk meningkatkan produktifitas pengerjaan pada proses Line Painting di bagian produksi. Fokus penelitian ini yaitu: untuk melihat pemborosanyang terjadi pada bagian proses tersebut hal ini dikarenakan pada proses tersebut produktivitas masih jauh dibawah target yang ditetapkan perusahaan, sehingga perlu adanya perbaikan pada proses tersebut. Perbaikan dilakukan dengan menggunakan konsep Lean yang digabungkan dengan metode PDCA. Dari hasil perbaikan yang dilakukan didapatkan hasil bahwa selama proses Line Painting banyak terjadi Waste loss time, lalu dilakukanlah perbaikan dengan penerapan Lean di dapatkan peningkatan atau perbaikan produktivitas sebesar 80,6\% yang sebelumnya produktivitas hanya mencapai $71 \%$. Dari penelitian ini dibuktikan bahwa dengan melakukan penerapan Lean ini dapat meningkatkan produktivitas yang cukup signifikan.
\end{abstract}

Kata Kunci:Kaizen, Lean, pemborosan, PDCA, Produktifitas

Received10 Januari | Revised26 Januari 2020 | Accepted26 Januari 2020

*Corresponding author at:Jl Raya Meruya Selatan No.1 Kembangan, Jakarta Barat 11650, Indonesia

E-mail address:hayu.kartika@mercubuana.ac.id 


\section{Pendahuluan}

Suatu perusahaan baik yang bergerak di bidang jasa maupun manufaktur, di dalam memberikan pelayanan jasa ataupun dalam menghasilkan sebuah produk, mempunyai satu tujuan akhir yang diharapkan dan diinginkan perusahaan yaitu, produk atau jasa yang dihasilkandapat diterima dan memenuhi keinginan pelanggan atau memenuhi suatu tuntutan dari pelanggan, karena pelanggan merupakan salah satu kebutuhan dari sebuah perusahaan yang berperan di dalam pembentukan sebuah image perusahaan serta mempengaruhi terhadap peningkatan pendapatan perusahaan. Oleh sebab itu,dalam rangka pemenuhan keinginan atau tuntutan dari pelanggan tersebut maka perlu adanya perbaikan-perbaikan proses yang secara terus menerus dilakukan.

Penelitian ini dilakukan pada sebuah perusahaan automotif dan perusahaan ini mempunyai permasalahan pada bagian produksi dimana produktifitas pada proses pengerjaan line painting yang dihasilkan pada perusahaan ini masih dibawah standar atau dibawah target perusahaan, serta masih ditemukannya pemborosan atau proses yang tidak memiliki nilai tambah (Non Value Added), Pemborosan ini perlu diminimalkan, hal ini dikarenakan dengan meminimalkan pemborosan maka dapat meningkatkan produktivitas dan efektivitas perusahaan.

Maka dari itu, penelitian ini dimaksudkan untuk mencari solusi untuk meningkatkan produktifitas pada proses line painting dengan menggunakan konsep Lean. Dimana produktifitas yang terjadi pada proses ini masih dibawah dari target perusahaan yaitu hanya sekitar rata-rata $70 \%$ sedangkan target perusahaan adalah sebesar $80 \%$. Ketidaksampaian dalam pencapaian target tersebut sangat berpengaruh terhadap output yang dihasilkan perusahaan, sehingga menimbulkan hasil output yang kurang maksimal. Lean manufacturing merupakan konsep untuk meningkatkan responsiveness melalui usaha pengurangan pemborosan (waste), continuous improvement dan cost reduction Untuk perbaikan yang akan dilakukan secara berkesinambungan pada penelitian ini akan menerapkan perbaikan dengan mencari solusi untuk menyelesaikan permasalahan dengan menerapkan atau menggunakan metode PDCA, dimana metode PDCA ini merupakan suatu metodologi pemecahan masalah iterative yang banyak diaplikasikan untuk pengendalian mutu secara statistik dan berkelanjutan [1] .

\section{Teori}

\subsection{Lean Manufacturing}

Lean manufacturing adalah suatu pendekatan sistematis untuk mengidentifikasi dan mengeliminasi pemborosan berupa aktivitas yang tidak memberi nilai lebih (non-value added activities) dapat disebut juga waste. Pemborosan atau waste, dalam bahasa Jepang disebut muda, merupakan segala sesuatu tindakan yang dilakukan tanpa menghasilkan nilai dengan cara melakukan perbaikan terus menerus dengan menerapkan aliran produksistem tarik (pull system) dari sudut pandang pelanggan untuk mencapai tujuan kesempurnaan terhadap kepuasaan pelanggan.[2] 


\subsection{Kaizen}

Kaizen dalam bahasa jepang adalah perbaikan secara berkelanjutan (continuous improvement).

Dalam kaizen memiliki beberapa metode yang dapat digunakan perusahaan dalam melakukan perbaikan, metode tersebut yaitu: 3M (Muda, Mura, dan Muri), gerakan 5S (Seiri, Seiton, Seiso, Seiketsudan shitsuke), PDCA, dan 5W+1H [3].

Menggunakan PDCA Cycle dan beberapa alat peningkatan, dapat mengetahui akar permasalahan dalam pengidentifikasian dan mencari solusi perbaikan dan Kaizen memainkan peran penting dalam menghilangkan kerugian dan pemborosan baik dalam produksi maupun non produksi.[4] . Dalamahapan-tahapan dalam siklus PDCA terinci dari bebreapa tahap, yaitu:
a. Mengembangkan rencana (Plan)
b. Melaksanakan rencana (Do)
c. Memeriksa atau meneliti hasil yang dicapai (Check)
d. Melakukan tindakan penyesuaian bila diperlukan (Action)

\subsection{Sistem Produksi}

Sistem produksi memiliki komponen atau elemen struktural dan fungsional yang berperan penting dalam menunjang kontinuitas operasional sistem produksi itu. Komponen atau elemen struktural yang membentuk sistem produksi terdiri dari : bahan (material), mesin dan peralatan, tenaga kerja, modal, energi, informasi, tanah dan lain-lain, Sedangkan komponen atau elemen fungsional terdiri dari : supervise, perencanaan, pengendalian, koordinasi, dan kepemimpinan, yang kesemuanya berkaitan dengan manajemen dan organisasi [5]. Selain sistem produksi yang telah dikenal secara umum, secara khusus dikenal pula istilah sistem manufaktur. Sistem manufaktur meliputi proses dari bahan baku sampai menjadi produk jadi melalui serangkaian operasi. Operasi-operasi ini meliputi kombinasi dari personil dan peralatan dengan tingkat otomasi yang bermacam-macam.Proses manufaktur dapat dibagi menjadi dua jenis proses utama yaitu : operasi proses (processing operations) dan operasi perakitan (assembly operations)[6] 


\section{Metode}

Untuk memecahkan suatu masalah dalam melakukan penelitian dibutuhkan langkah - langkah yang sistematis agar pendekatan dan model dari masalah tersebut bisa diuraikan. Langkah langkah yang bisa digunakan adalah sebagai berikut:

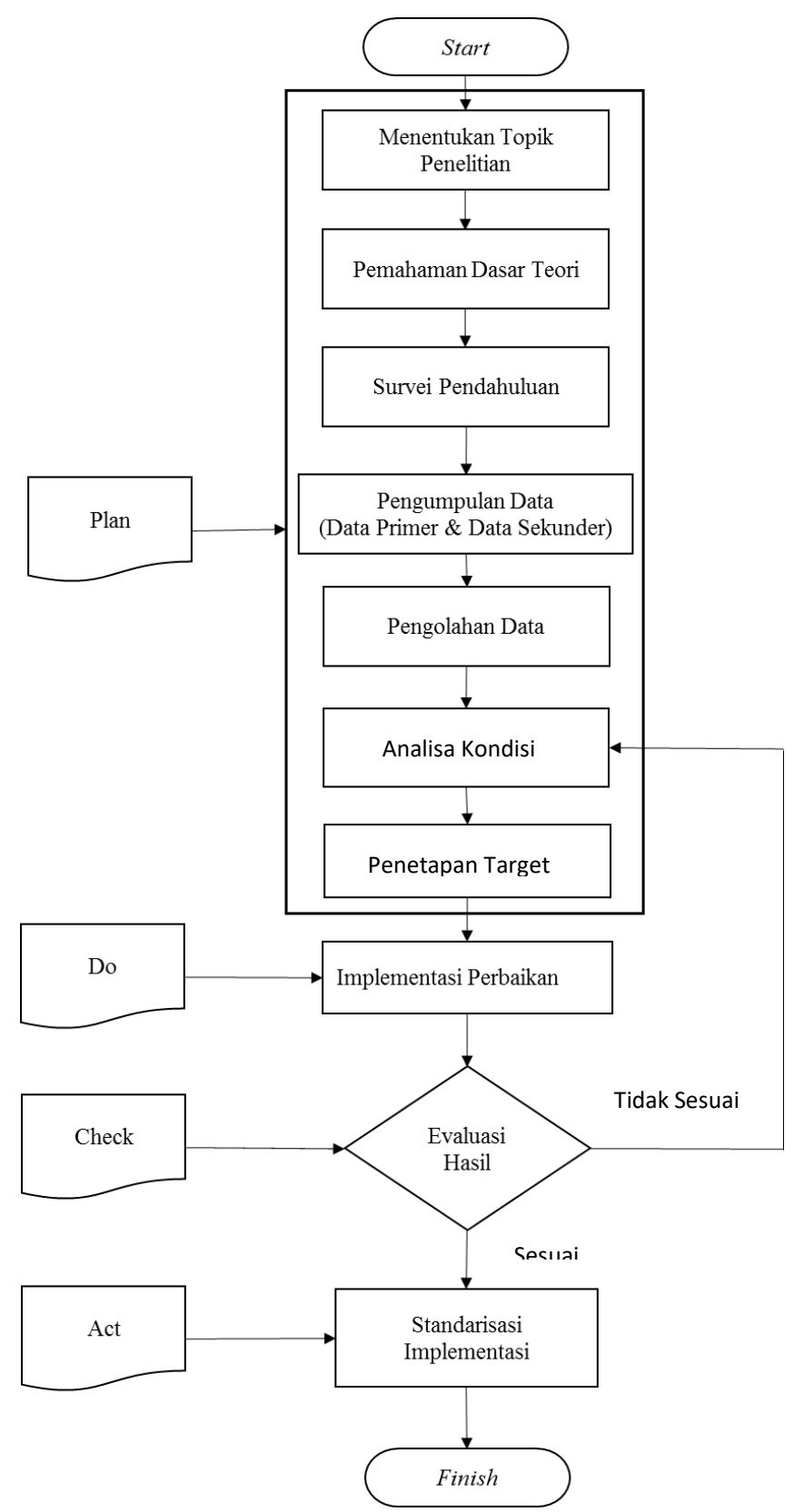

Gambar 1 Diagram Alir Penelitian

Dari gambar 1 diatas, tahapan-tahapan yang digunakan pada penelitian ini menggunakan metode PDCA, yaitu:

1. Tahap Plan diawali dengan memahami dasar teori yang akan dipakai dalam pengimpelemtasian dengan diikutisurvei kondisi pada bagian produksi setelah itu dilakukan pengumpulan data. Data lalu diolah untuk mengetahui kondisi produktifitas di perusahaan dan dijabarkan dengan menganalisa kondisi yang ada di perusahaan serta melakukan penetapan target untuk perbaikan yang akan dilakukan [7] 
2. Tahap Do akan dilakukan sebuah implementasi perbaikan yang akan dilakukan

3. Tahap Check dilakukan evaluasi hasil dari implementasi perbaikan, jika hasil belum mencapai target yang diinginkan maka akan kembali melihat ke permasalahan kondisi yang terjadi

4. Tahap Action jika hasil pebaikan telah sesuia maka perbaikan yang telah dilakukan akan di standarisasi dan akan diimplementasikan pada proses kerja di perusahaan tersebut [8]

\section{Hasil dan Pembahasan}

Dalam mengatasi permasalahan yang terdapat diperusahaan, penelitian ini menggunakan metode PDCA, dimana setiap tahapan akan tergambarkan pada pembahasan ini

\subsection{Tahap Plan (Perencanaan)}

Dalam setiap proses manufaktur pasti mempunyai target produktivitas yang sudah ditentukan oleh management. Dimana target produktivitas line painting yang sudah ditentukan oleh management yaitu sebesar 80\%. Jika dilihat aktual Maret 2019 ke belakang, produktivitas line painting belum ada yang mencapai target [9].

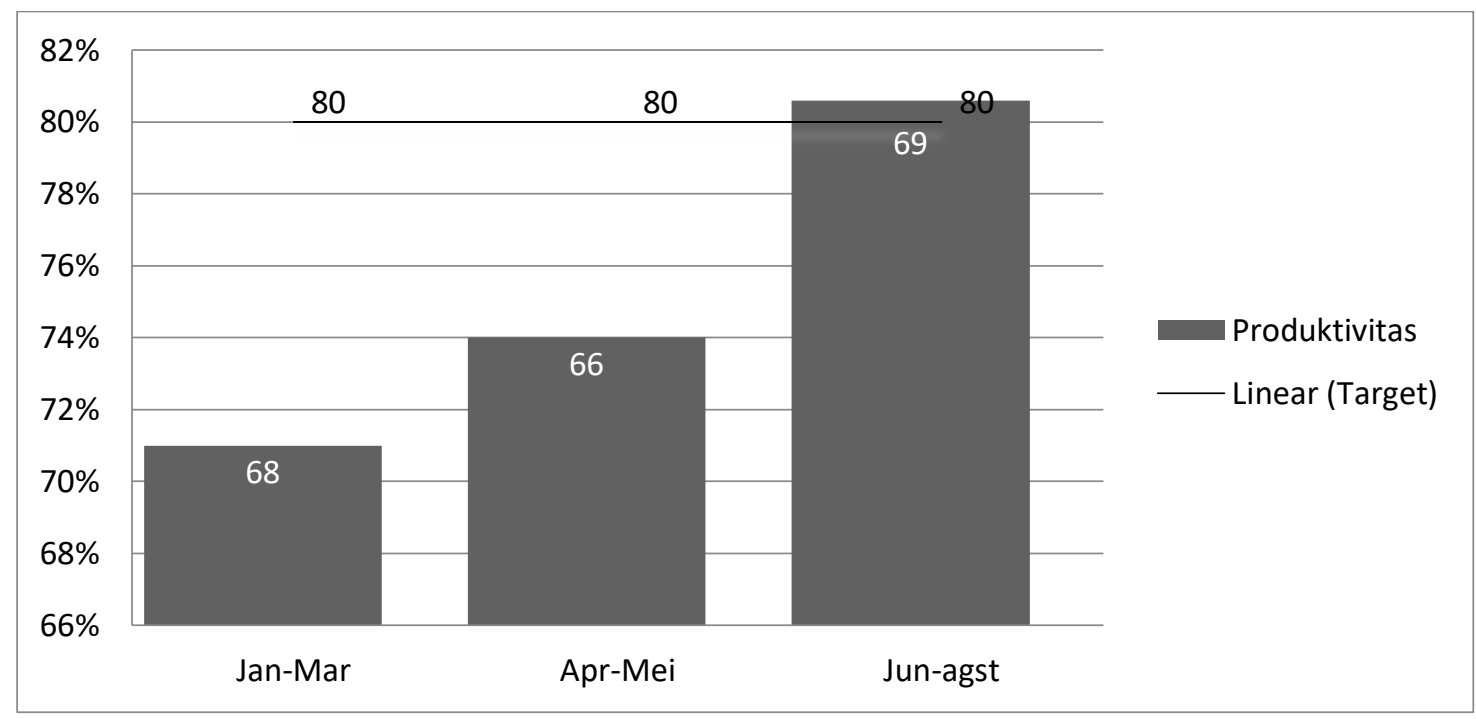

Gambar 2 Grafik Produktivitas Line Painting Maret 2018 - Maret 2019

Dapat dilihat dari grafik, rata-rata pencapaian produktivitas selama setahun ke belakang sebesar $71 \%$. Sementara target yang ditentukan oleh perusahaan sebesar $80 \%$. Berdasarkan hal tersebut maka peneliti menganalisa di tiap - tiap proses produksi di line painting. Didapapatkan permasalahan yang menyebabkan tidak tercapainya produktifitas yaitu permasalahan banyaknya terjadinya losstime pada proses line painting, losstime ini merupakan salah satu bentuk pemborosan dalam hal waktu menunggu (Waste Waiting). Dalam sebuah penelitian juga menyebutkan akar penyebab dari waste waiting disebabkan karena waktu yang tidak dimaintain [10]. Berikut beberapa aktivitas yang menyebabkan terjadinya losstime dapat dilihat pada gambar 3 dibawah ini: 


\section{Lost Time Line Painting}

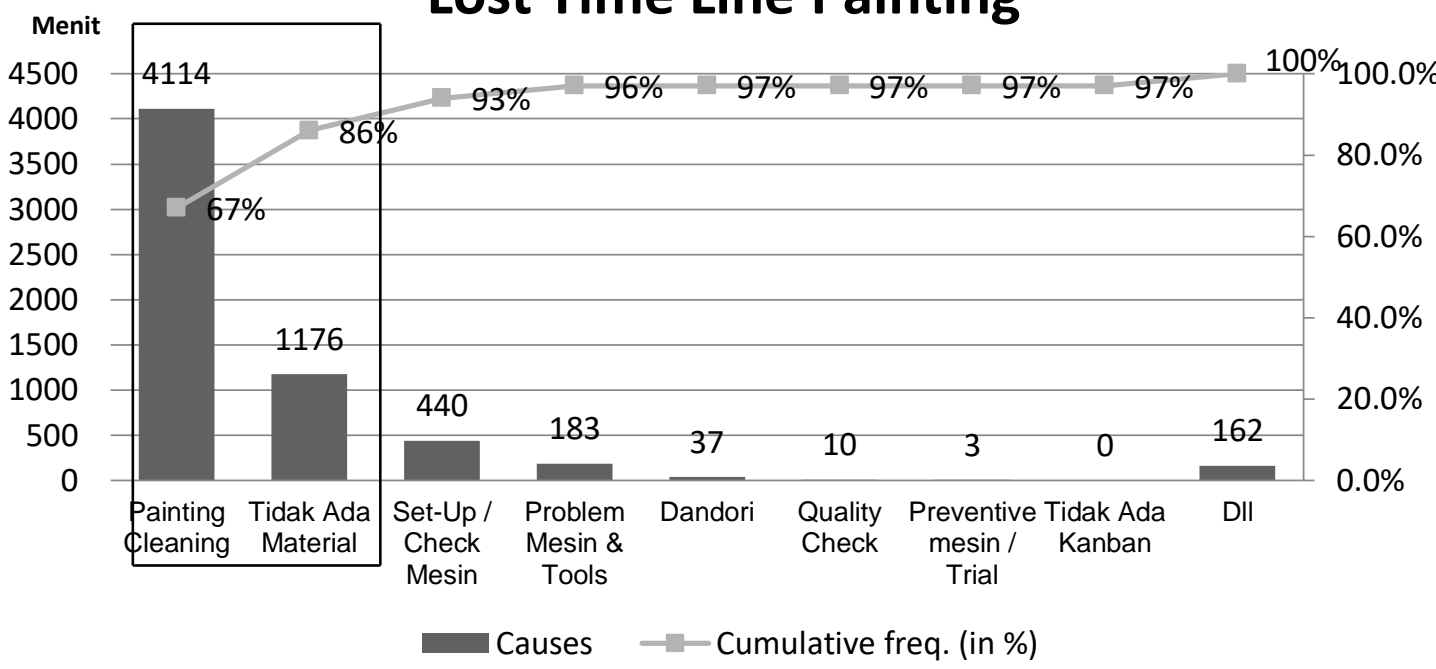

Gambar 3Aktivitas losstime Line Painting

Dapat Dilihat dari gambar 3 diatas penyebab losstime yang terbesar yaitu disebabkan oleh activity painting cleaning dan juga tidak adanya material. Kedua problem tersebut yang mengganggu kelancaran produksi di line painting dan termasuk kedalam jenis waste dalam produksi. Maka dari itu, penulis akan membahas lebih lanjut terkait permasalahan yang menyebabkan produktivitas line painting tidak mencapai targetnya.

\section{$\underline{\text { Analisa Kondisi yang ada }}$}

Berdasarkan pembahasan diatas yang menyebabkan menurunnya produktivitas line painting yaitu losstime painting cleaning dan tidak adanya material. Keduanya saling berkaitan terhadap kelancaran produksi line painting.

Permasalahan pertama yaituPainting Cleaning merupakan suatu aktivitas yang dilakukan untuk mempersiapkan line sebelum berjalan dengan normal dan juga aktivitas yang dilakukan untuk mengurangi rejection in line. Painting cleaning terbagi menjadi 3 waktu dalam satu kali produksi. 3 waktu tersebut yaitu sebelum mulai produksi, ketika produksi berlangsung, dan di akhir produksi. Dalam waktu 3 bulan tersebut losstime yang disebabkan painting cleaning sebesar 4114 Menit.

Permasalahan kedua yaitu: tidak adanya material kondisi ini merupakan ketidaktersedianya material injeksi di dalam chute before painting. Akibatnya proses painting harus stop line karena menunggu material dari proses sebelumnya. Identifikasi dalam waste termasuk kedalam jenis waiting. Dalam waktu 3 bulan tersebut losstime yang disebabkan tidak adanya material sebesar 1176 Menit. 


\section{$\underline{\text { Penetapan Target }}$}

Target perbaikan produktifitas ini adalah dengan memenuhi target yang diinginkan perusahaan yaitu sebesar $80 \%$. Ini merupakan minimal target yang akan dicapai dalam penelitian ini.

\subsection{Tahap Do (Perbaikan)}

\section{Implementasi perbaikan}

Sebelum melakukan perbaikan dilakukan proses pengindentifikasian terhadap problem yang ada dengan diagram tulang ikan yaitu dapat dilihat pada gambar 4

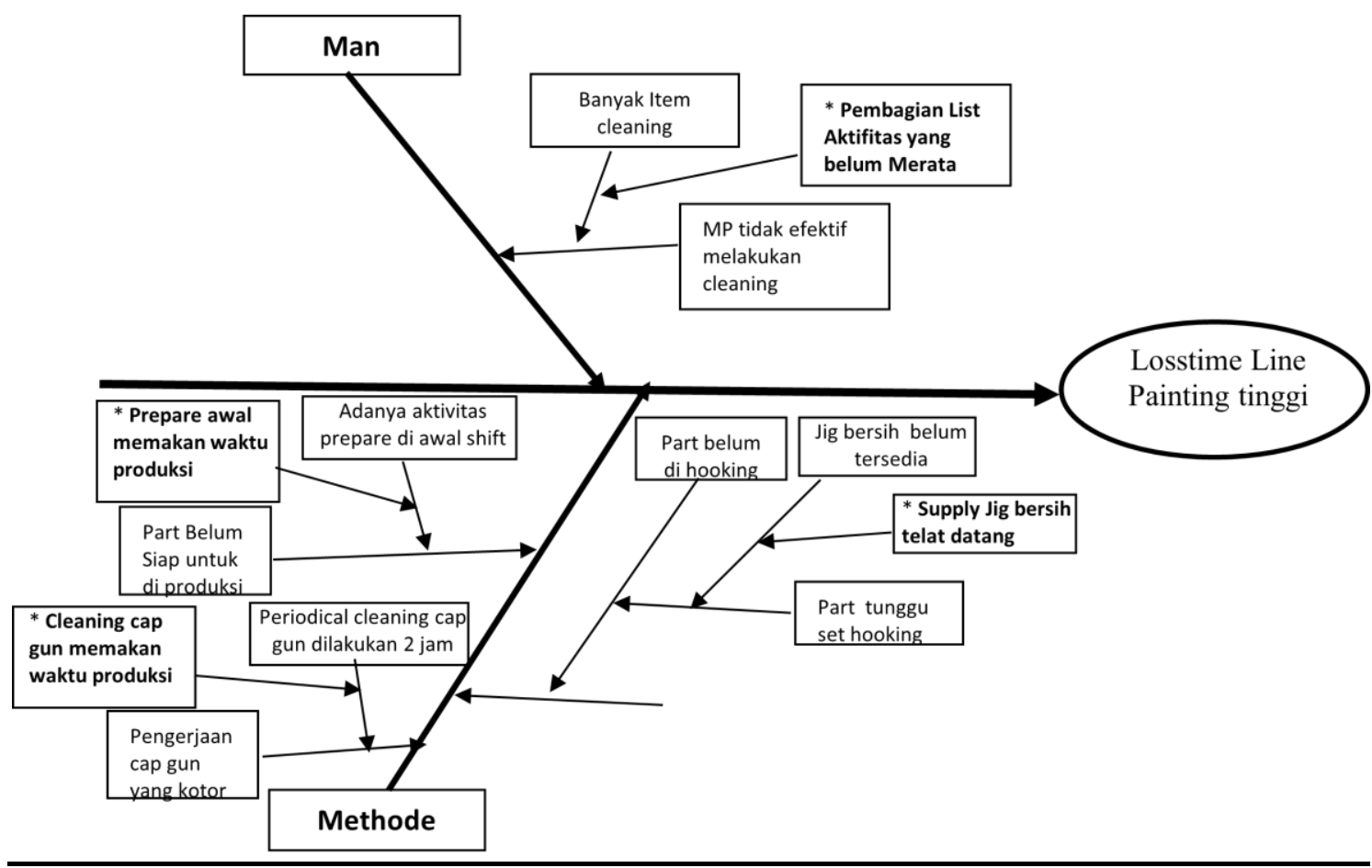

Gambar 4 Diagram Tulang Ikan

Berdasarkan fishbone diagram diatas, terdapat bebrapa faktor penyebab tingginya losstime pada bagian line painting, yaitu:

\section{a. Faktor Methode}

1. Prepare awal memakan waktu produksi.

2. Cleaning cap gun memakan waktu produksi.

3. Supply jig bersih telat datang.

b. Faktor Man

1. Pembagian list aktivitas yang belum merata.

Dari masalah yang didapatkan diatas lalu dibuatlah implementasi perbaikan yang akan dilakukan dapat dilihat pada tabel 1 dibawah ini: 
Tabel 1 Implementasi Perbaikan

\begin{tabular}{clccccc}
\hline No. & \multicolumn{1}{c}{ WHY } & WHAT & WHEN & WHO & WHERE & HOW \\
\hline MUCH
\end{tabular}

\subsection{Tahap Check (Pemeriksaan hasil)}

Setelah mengimplementasikan perbaikan dari Tabel 1 diatas pada tahap ini akan dilakukan pengecekan hasil perbaikan. Hasil perbaikan dapat dilihat dari penurunan loss timepada line paintingyang dapat dilihat pada gambar 5

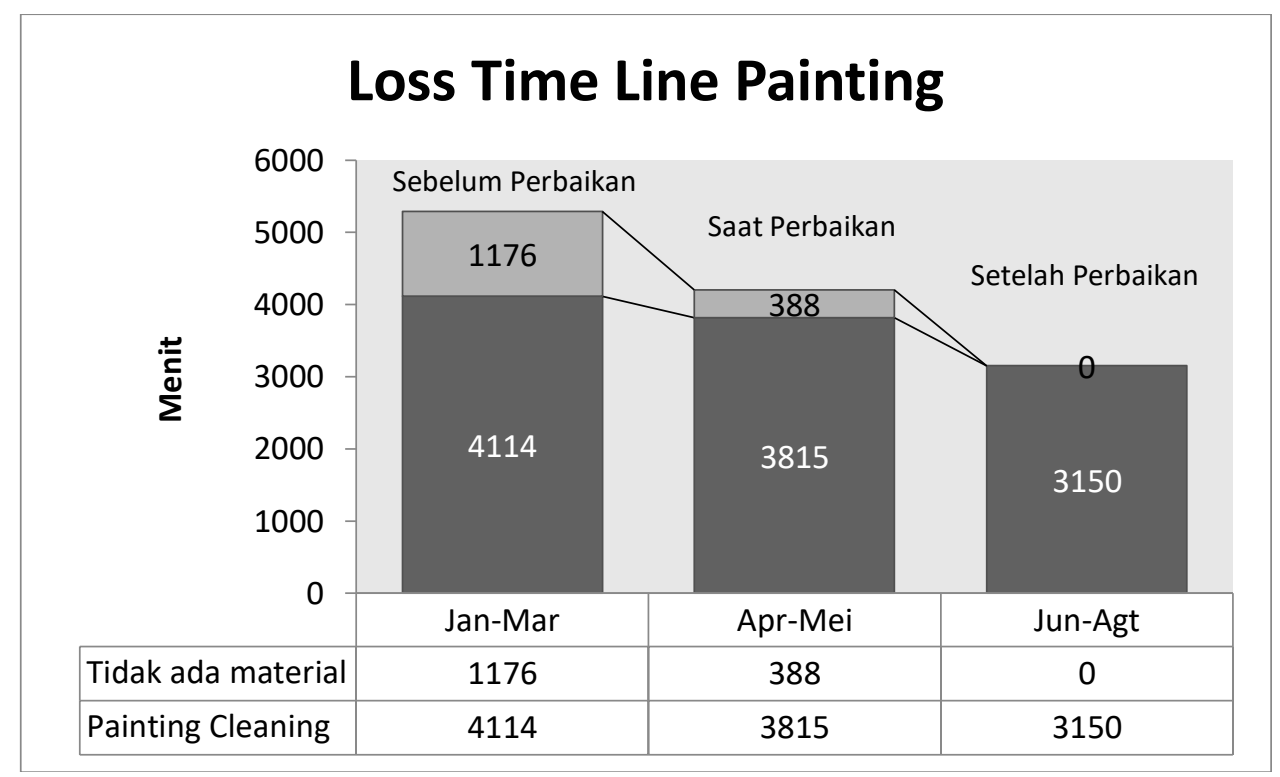

Gambar 5 Grafik Penurunan Losstime Line Painting

Berdasarkan grafik diatas penurunan losstime pada aktifitas painting cleaning mencapai 964 menit dan untuk losstime untuk masalah tidak adanya material menjadi 0 menit. Maka total losstime setelah pebaikan sebesar 2140 menit

\subsection{Tahap Action (Tindakan)}

Tahapan terakhir dalam PDCA adalah act (Mengambil Tindakan). Terdapat 2 tindakan pada tahapan kali ini yakni eliminasi waste dan standarisasi. Berdasarkan hasil perbaikan yang telah dievaluasi maka dilakukanlah hal ini :

1. Eliminasi waste line painting

Waste merupakan hal yang tidak ada nilai tambahnya (Non value added). Maka dari itu perlu dilakukan eliminasi waste di line painting ini dikarenakan waste 
tersebut mengganggu kelancaran proses produksi painting sehingga productivity line tersebut tidak tercapai target.

2. Standarisasi terhadap beberapa aktifitas untuk line painting dapat dilihat pada tabel 2

Tabel 2. Standarisasi

\begin{tabular}{clc}
\hline No. & \multicolumn{1}{c}{ Standarisasi } & Periode \\
\hline \multirow{2}{*}{1} & Standar Item Check Prepare awal produksi dan Cleaning & Harian \\
& Akhir shift & Harian \\
2 & One Point Lesson Proses Cleaning Cap Gun & Harian \\
3 & Checksheet Kedatangan Supplier Jig Painting & \\
\hline
\end{tabular}

Setelah adanya standarisasi tersebut, untuk selanjutnya yaitu pengontrolan secara berkala terhadap standarisasi yang telah dibuat. Karena hal tersebut merupakan bagian dari evaluasi terhadap standard yang telah diterapkan sehingga konsep perbaikan ini akan terus berjalan untuk kemajuan Dept. Production Body Painting kedepannya.

\subsection{Hasil dan Pembahasan}

Hasil yang didapatkan pada penelitian ini adalah penurunan losstime yang berpengaruh terhadap peningkatan produktifitas line painting. Dapat dilihat pada gambar 6. Dengan mengeliminasi beberapa waste yang ada di line painting terlihat pada tabel berikut:

Tabel 3. Eliminasi Waste

\begin{tabular}{|c|c|c|c|c|}
\hline No. & $\begin{array}{c}\text { Activity Sebelum } \\
\text { Perbaikan }\end{array}$ & $\begin{array}{c}\text { Jenis } \\
\text { Waste } \\
\end{array}$ & Activity Setelah Perbaikan & $\begin{array}{c}\text { Eliminasi } \\
\text { Waste }\end{array}$ \\
\hline 1 & $\begin{array}{l}\text { Prepare Sebelum } \\
\text { Produksi }\end{array}$ & Waiting & $\begin{array}{l}\text { 1. Akhir shift } 3 \text { menyediakan part } \\
\text { pada carryng in } \\
\text { 2. MP melakukan prepare lebih } \\
\text { awal }\end{array}$ & $\begin{array}{l}\text { Waiting } \\
\text { berkurang } \\
\text { 30' }\end{array}$ \\
\hline 2 & $\begin{array}{l}\text { Cleaning Cap } \\
\text { Gun }\end{array}$ & Waiting & $\begin{array}{l}\text { Cleaning cap gun dilakukan saat } \\
\text { istirahat dengan catatan istirahat } \\
\text { gantian }\end{array}$ & $\begin{array}{l}\text { Waiting } \\
\text { berkurang } \\
30\end{array}$ \\
\hline 3 & $\begin{array}{l}\text { Cleaning Akhir } \\
\text { Shift }\end{array}$ & $\begin{array}{l}\text { Waiting \& } \\
\text { Over } \\
\text { Processing }\end{array}$ & $\begin{array}{l}\text { Pengevektivan kerja dengan } \\
\text { pembagian kerja yang merata dan } \\
\text { ditambah } 1 \text { MP support }\end{array}$ & $\begin{array}{l}\text { Waste } \\
\text { berkurang } \\
\quad 45\end{array}$ \\
\hline
\end{tabular}




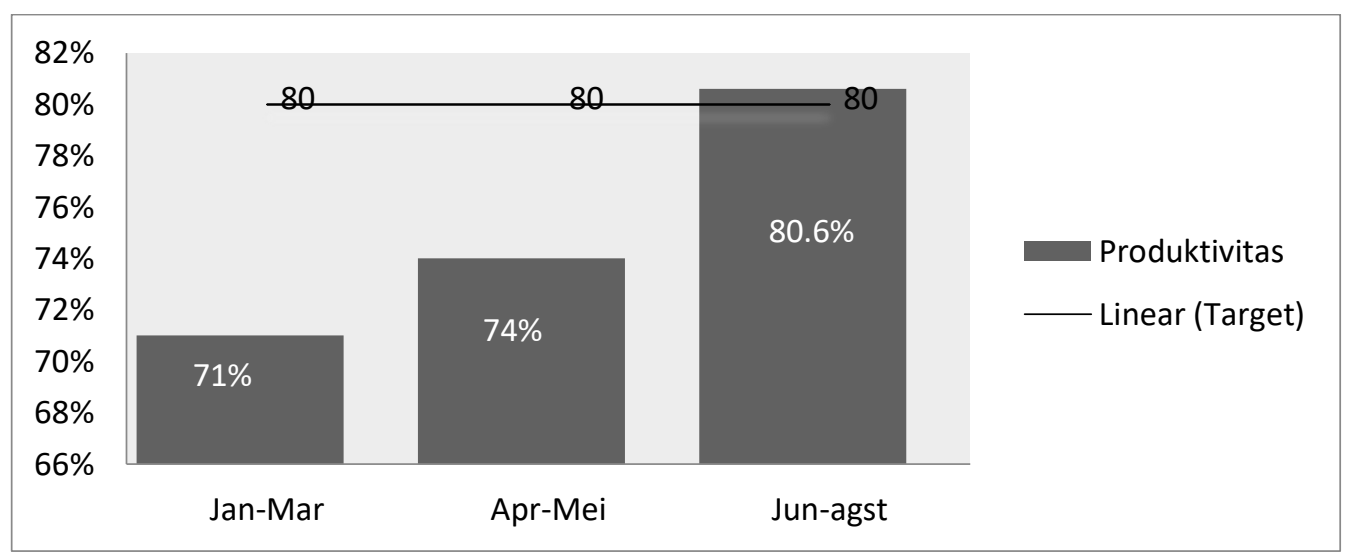

Gambar 6 Peningkatan Produktifitas Line Painting (kartika, et al, 2019)

Peningkatan yang terjadi hingga 10,6\% untuk produktifitas dari line painting hal ini telah mencapai target yang diinginkan. Selain itu hasil dari peningkatan produktifitas juga dapat dilihat dari segi SQCDMPE (Safety, Quality, Cost, Delivery, Moral, Productivity) dapat dilihat pada tabel 4

Tabel 4 Analisa SQCDMPE

\begin{tabular}{|c|c|c|}
\hline No. & Parameter & Hasil Setelah Perbaikan \\
\hline 1 & Safety & - \\
\hline 2 & Quality & - \\
\hline 3 & Cost & $\begin{array}{l}\text { Hasil produksi yang meningkat sekitar } 50 \text { jig dan mengurangi } \\
\text { Line stop akibat losstime sebesar Rp. } 407.028 .000 / \text { tahun }\end{array}$ \\
\hline 4 & Delivery & $\begin{array}{l}\text { Pengiriman part akan terjamin karena kapasitas produksi } \\
\text { meningkat akan menjamin ketersediaan stock }\end{array}$ \\
\hline 5 & Moral & $\begin{array}{l}\text { MP menjadi lebih percaya diri karena kondisi line meningkat } \\
\text { dan bisa memaksimalkan pekerjaan mereka. }\end{array}$ \\
\hline 6 & Productivity & Productivity Line Painting meningkat sebesar $10,6 \%$ \\
\hline 7 & Environment & - \\
\hline
\end{tabular}

\section{Kesimpulan}

Berdasarkan penelitian yang telah dilakukan, kesimpulan yang dapat diambil dari penelitian ini adalah sebagai berikut:terjadi peningkatan produktivitas padaline painting sebesar $80,6 \%$ dan telahmelebihi capaian target yang diinginkan sebesar $80 \%$. Peningkatan produktifitas ini dilakukan dengan cara mengurangi waste losstime Painting Cleaning dan Menghilangkanwaste Losstime Tidak ada Material dengan total losstime yang dihilangkan sebesar 2140 menit.

\section{Ucapan Terima Kasih}

Penulis mengucapkan terima kasih kepada semua pihak yang mendukung hasil penelitian ini, dan juga kepada Universitas Mercu Buana yang telah mendukung penyelesaian dalam penelitian ini. 


\section{DAFTAR PUSTAKA}

[1] Azwir,Hamdi, H., \& Setyanto, Kurniawan, A, Analisis penerapan lean manufacturing pada penurunan cacat Feed Roll menggunakan metode PDCA 9studi kasus PT. XYZ). Jurnal Rekayasa Sistem Industri Vol 6 No.2:p.105-117. 2017

[2] Adrianto, Wahyu., \& Kholil, Muhammad, Analisa Penerapan Lean Production Process untuk mengurangi Lead time Process Perawatan Engine (Studi Kasus PT. GMF AEROASIA). Jurnal Optimasi Sistem Industri. 2017

[3] Fatkhurrohman, A., \& Subawa. Penerapan kaizen dalam meningkatkan efisiensi dan kualitas produk pada bagian banbury pt bridgestone tire indonesia. Jurnal Administrasi Kantor, 4(1): p.14-31. 2016

[4] Jakfar, A., Setiawan, W. E., \& Masudin, I. Pengurangan Waste Menggunakan Pendekatan Lean Manufacturing. Jiti, I: p. 43-53. 2014

[5] Kartika, Hayu., \& Hastuti, Tri.Analisa Pengaruh Sikap Kerja $5 S$ dan Faktor Penghambat Penerapan 5S Terhadap Efektifitas Kerja Departemen Produksi di Perusahaan Sepatu. Jurnal Ilmiah PASTI Vol V Edisi 1: p. 47-54. 2011

[6] Khanan, Abdul S,M,. \& Haryono,Analisis Penerapan Lean Manufacturing untuk Menghilangkan Pemborosan di Lini Produksi PT Adi Satria Abadi.Jurnal Rekayasa Sistem Industri Vol. 4, No. 1: p. 47-54. 2015

[7] Kurniawan, Taufik. Perancangan Lean Manufacturing dengan Metode VALSAT pada Line Produksi Drum Brake Type IMV (Studi Kasus: PT Akebono Brake Astra Indonesia). Universitas Indonesia: Depok. 2012

[8] Nasution, M.,N.,Total Quality Management. Bogor. Ghalia IndonesiaSharma, Puneet.,Sharma, Kumar, N., \& Singh, P,M. Productivity Upswing Through TwoPhase continuous Process improvement Model: The Case of Apparel manufacturer. Journal of Tekstil ve Konfeksion.2015

[9] Wignjosoebroto, Sritomo.Ergonomi, Studi Gerak dan Waktu. GunaWidya,Surabaya.2003

[10] Wignjosoebroto, Sritomo.Pengantar Teknik dan Manajemen Industri. Guna Widya,Surabaya.2003 